\title{
SPACE HEATING FOR OFFICE BUILDING AT GLENWOOD SPRINGS, COLORADO
}

\author{
Kenneth L. Garing \\ Glenn E. Coury
}

Published March 1982

Coury and Associates, Inc.

Lakewood, Colorado 80226

DISTRIBUTIOH OF THIS BOCUMEAT IS UMLIMATED

Prepared for EG\&G Idaho, Inc. Under Subcontract No. K-7835 


\section{DISCLAIMER}

This report was prepared as an account of work sponsored by an agency of the United States Government. Neither the United States Government nor any agency Thereof, nor any of their employees, makes any warranty, express or implied, or assumes any legal liability or responsibility for the accuracy, completeness, or usefulness of any information, apparatus, product, or process disclosed, or represents that its use would not infringe privately owned rights. Reference herein to any specific commercial product, process, or service by trade name, trademark, manufacturer, or otherwise does not necessarily constitute or imply its endorsement, recommendation, or favoring by the United States Government or any agency thereof. The views and opinions of authors expressed herein do not necessarily state or reflect those of the United States Government or any agency thereof. 


\section{DISCLAIMER}

Portions of this document may be illegible in electronic image products. Images are produced from the best available original document. 


\section{PREFACE}

This report was prepared for EG\&G Idaho by Coury and Associates, Inc., on Subcontract No. K-7835 under the Department of Energy's Outreach Program. It is now being reissued as an
EG\&G formal report in order to make it available to others who may be interested in this geothermal application. 


\section{FOREWORD}

The Geothermal Technical Assistance Program was developed under the premise that the majority of groups or individuals with available geothermal resources do not have the experience or manpower necessary to do a preliminary engineering and economic feasibility evaluation for geothermal energy projects. In order to disseminate technical information and to facilitate expanded use of geothermal energy resources, assistance was provided through FY-1981 in a consulting format on a first-come, staff-andfunds-available basis. Technical assistance can relate to conceptualization; engineering; economics; water chemistry implications for environmental, disposal, and material selection considerations; and planning and development strategies. This report is one of a series adapted from consultation provided to requesters either through in-house efforts or through limited efforts subcontracted to local engineering firms. The Geothermal Technical Assistance (GTA) Reports in this series, which are listed below, will be available for purchase early in 1982 by those with interest in specific geothermal applications from the U.S. National Technical Information Service:

U.S. Department of Commerce, National Technical Information Service, 5285 Port Royal Road, Springfield, VA 22161, (703) $557-4650$

GTA Report Number

1.

2.

3.

4.

5.

6.

7.

8.

9.
EG\&G

Report Number

*EGG-GTH-5512

•EGG-GTH-5521

*EGG-GTH-5573

*EGG-GTH-5574

*EGG-GTH-5575

*EGG-GTH-5599

EGG-GTH-5617

*EGG-2137

*EGG-2138
Title

Aquaculture Facility Potential at Boulder Hot Springs, Boulder, Montana

Preliminary Geothermal Disposal Considerations, State Health Laboratory, Boise, Idaho

Geothermal Conversion at Veterans Hospital, Boise, Idaho

Geothermal Applications for Highway Rest Areas

Geothermal Applications for a Tannery

Preliminary. Conceptual Design for Geothermal Space Heating Conversion of School District 50 Joint Facilities at Pagosa Springs, Colorado

Selected Geothermal Technical Assistance Efforts (comprising short descriptions of ten space heating projects, five district heating projects, and three heat exchanger projects)

Geothermal Source Potential and Utilization for Methane Generation and Alcohol Production (subcontractor report)

Geothermal Source Potential and Utilization for Alcohol Production (subcontractor report) 
GTA

$\underline{\text { Report Number }}$

10.

11.

12.

13.

14.

15.

16.

17.

18.

19.

20.

21.

22.

23.

24.

25.
*EGG-2144

*EGG-2145

EG\&G

Report Number

*EGG-2139

EGG-2146

EGG-2147

*EGG-2148

EGG-2149

EGG-2150

EGG-2151

EGG-2152

EGG-2153

EGG-2154

EGG-2155

EGG-2156

*EGG-GTH-5739

*EGG-GTH-5740
Title

Potential Geothermal Energy Applications for Idaho Elks Rehabilitation Hospital (subcontractor report)

Technical Assistance Report on a Geothermal Heating Utility for Lemmon, South Dakota (subcontractor report)

Economic Analysis for Utilization of Geothermal Energy by North Dakota Concrete Products Company (subcontractor report)

Geothermal Feasibility Analysis II for Polo School District No. 29-2, South Dakota (subcontractor report)

Preliminary Feasibility Study of Heating and Cooling Alternatives for Nebraska Western College, Scottsbluff, Nebraska (subcontractor report)

Inventory of Thermal Springs and Wells Within a OneMile Radius of Yucca Lodge, Truth or Consequences, New Mexico (subcontractor report)

Space Heating for Spa Facilities at Ojo Caliente, New Mexico (subcontractor report)

Space Heating for Office Building at Glenwood Springs, Colorado (subcontractor report)

District Heating for Subdivision in Dickinson, North Dakola (subcontractor report)

Space Heating for Subdivision in Truth or Consequences, New Mexico (subcontractor report)

Space Heating for Veterans Administration Medical Center, Marlin, Texas (subcontractor report)

District Heating for Subdivision in Castle Rock, Colorado (subcontractor report)

Space Heating for Twin Lakes School Near Gallup, New Mexico (subcontractor report)

Pumping Tests of Well Campbell Et Al. No. 2, Gila Hot Springs, Grant County, New Mexico (subcontractor report)

Geothermal Deicing of Bridge Structures

Assessment of a Geothermal Application at Tucson, Arizona 
GTA

Report Number

26.

27.

28.

29.

EGG-GTH-5812

EG\&G

Report Number

*EGG-GTH-5741

EGG-GTH-5779

EGG-GTH-5804

*Published as of $3 / 15 / 82$.
Title

Heat Pump Systems for Spring Creek, Montana

Pipe Selection Guide

An Overview of Engineering and Agricultural Design Considerations of the Raft River Soil-Warming and Heat-Dissipation Experiment

Design of the Glenwood Springs Downhole Heat Exchanger 
TECHNICAL ASSISTANCE REPORT

GEOTHERMAL HEATED OFFICE BUILDING

AT GLENWOOD SPRINGS, COLORADO

Final Report

Kenneth L. Garing

Glenn E. Coury

February 1982

Coury and Associates, Inc.

Lakewood, Colorado 80226

Prepared for Wright Water Engineers

Under Subcontract No. K-7835

With EG\&G Idaho, Inc. 


\section{CONTENTS}

\section{Page}

Abstract..........................

I. Introduction and Design Basis $\ldots \ldots \ldots \ldots \ldots \ldots \ldots \ldots \ldots$

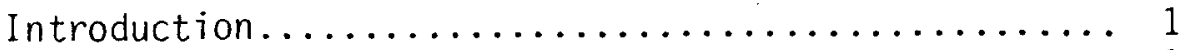

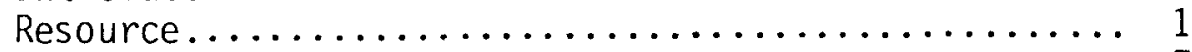

Building Design ............................. 7

II . Process Design......................... 10

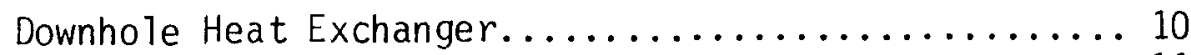

Surface Heat Exchangers................... 11

Application to the Wright Water Engineers System..... 12

Materials Selection....................... 14

II . Economic Considerations................... 17

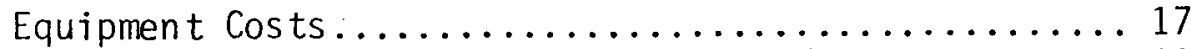

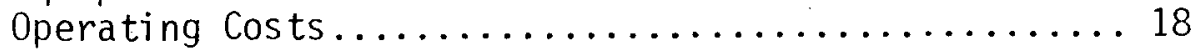

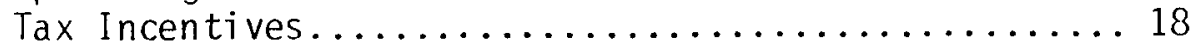

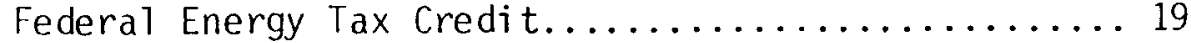

Intangible Drilling Cost Deductions............ 20

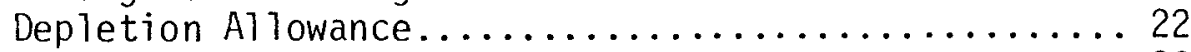

Colorado Energy Tax Credit.................. 23

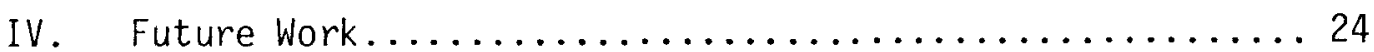




\section{Coury and Associates, Inc.}

\section{ABSTRACT}

Coury and Associates, Inc. was contracted by EG\&G Idaho, Inc. to provide technical assistance in a preliminary design and economic evaluation of a geothermal heating system for Wright Water Engineers. The use of a downhole heat exchanger was evaluated, with the objective of reducing costs in this first stage of the project, but was abandoned. The low resource temperature and lack of sufficient aquifer data were the reasons for abandonment of the downhole heat exchanger concept. The use of surface plate heat exchangers was selected as the preferred approach for utilizing the geothermal resource. Brine will be passed through three plate heat exchangers in the building basement. Separate loops of clean circulating fluid will be used to extract heat from the brine in three heat exchangers, with the loops providing heat to the building, a hot tub, and a deicing system. The cooled geothermal fluid from the heat exchangers will be injected to an isolated injection zone at the bottom of the production well. Aquifer tests are required to develop final pump sizes and process flows. The report that follows presents the information developed from the work tasks of this project. 


\section{Coury and Associates, Inc.}

\section{INTRODUCTION AND DESIGN BASIS}

\section{INTRODUCTION}

Wright Water Engineers is in the process of designing and constructing a new office building in Glenwood Springs, Colorado. This building is to make use of the geothermal resource underlying the property to provide heat for space conditioning and hot water. EG\&G Idaho, Inc. contracted with Coury and Associates, through the DOE Technical Assistance Program, to provide assistance in the design of the geothermal system for Wright Water Engineers.

This report is presented in four sections, titled Introduction and Design Basis, Process Design, Economic Considerations, and Future Work. In the first section, Introduction and Design Basis, the resource and building design are discussed. In the second section, Process Alternatives, a discussion of the advantages and disadvantages of both downhole and plate heat exchangers are presented. Also, in this chapter, information regarding the preferred approach for geothermal utilization and materials selection is provided. In the third section, Economic Considerations, the capital costs, operating costs, and tax incentives are detailed. In the last section, Future Work, several topics are addressed which deal with continued efficient use of the geothermal resource and operating equipment.

\section{RESOURCE}

The geothermal resource in the Glenwood Springs area has been used for more than 100 years. During this time period the use has been limited primarily to using flowing hot springs for the direct heating of a large outdoor swimming pool and the space heating of an adjoining hotel. The temperature of alt the flowing springs has been about $125^{\circ} \mathrm{F}$.

The surface manifestations and available geology indicate a source temperature of the geothermal resource greater than $150^{\circ} \mathrm{F}$. This $150^{\circ} \mathrm{F}$ temperature was the initial target for the well drilling program of Wright Water. A geothermal well drilling permit was obtained from the Colorado 
Coury and Associates, Inc.

$0 i 1$ and Gas Conservation Commission to drill on the Wright Water property.

Drilling was started in mid-August using a cable tool drill rig. Alluvial material was encountered for the first 98 feet of drilling. A 16-inch hole was drilled to about 103 feet and then cased with a 14-inch liner. A 13 5/8-inch hole was then drilled to about 130 feet and set with 12-inch casing. From this depth to 350 feet an $117 / 8$-inch hole was drilled and left open hole. The cable tool rig then moved off hole in mid-0ctober. A temperature profile of the well was made which showed a maximum temperature of $124^{\circ} \mathrm{F}$. A decision was then made to deepen the hole by about 200 feet and penetrate the Leadville Limestone to locate warmer water. A reverse rotary drill rig moved over the hole on october 19, 1981. The hole was drilled to a total depth of 570 feet by October 22, 1981. The well is open hole from 130 feet to 570 feet. Figure 1 is a schematic diagram of the well as drilled.

During the reverse rotary drilling process, more than 300,000 gallons of cold city water $\left(50^{\circ} \mathrm{F}\right.$ to $\left.60^{\circ} \mathrm{F}\right)$ were pumped into the hole. The temperature logs show that this water was injected in the zone from 250 to 350 feet. This indicates a very permeable zone at these depths. A temperature log taken three days after the drilling is shown in Figure 2. Based on the caliper $\log$, the well is sloughing between 130 and 370 feet. The hole ranges in size from 12 to 30 inches. Figure 3 shows the profile of the well based on the caliper log.

After deepening the we11 to 570 feet, the temperature increased to only $125^{\circ} \mathrm{F}$. This was the maximum temperature recorded three days after drilling stopped. No other temperature logs have been run. No samples of the water have yet been taken. However, the water is expected to be similar to the Glenwood Springs analysis, which is presented in Table 1.

Initially it had been hoped that a downhole heat exchanger could be used, but due to the low temperature this possibility was discounted. Thus, the fluid must be brought to the surface and then discharged to the surface or reinjected back into the ground. The cost for a separate reinjection well would have been high and space availability was also a concern. The decision was made to use the one well for both production and reinjection. 


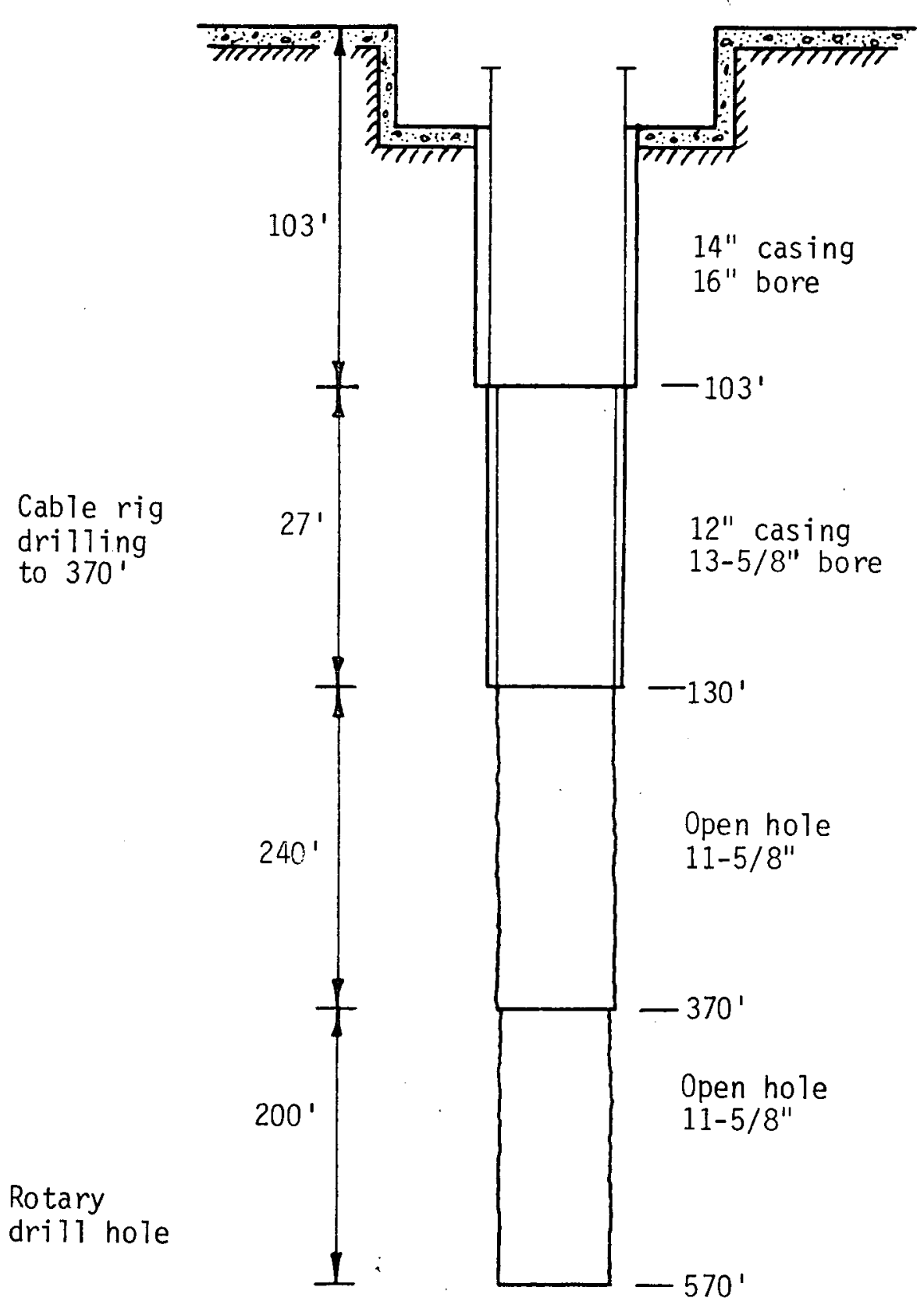

Figure 1. Schematic Drawing of Geothermal We11 


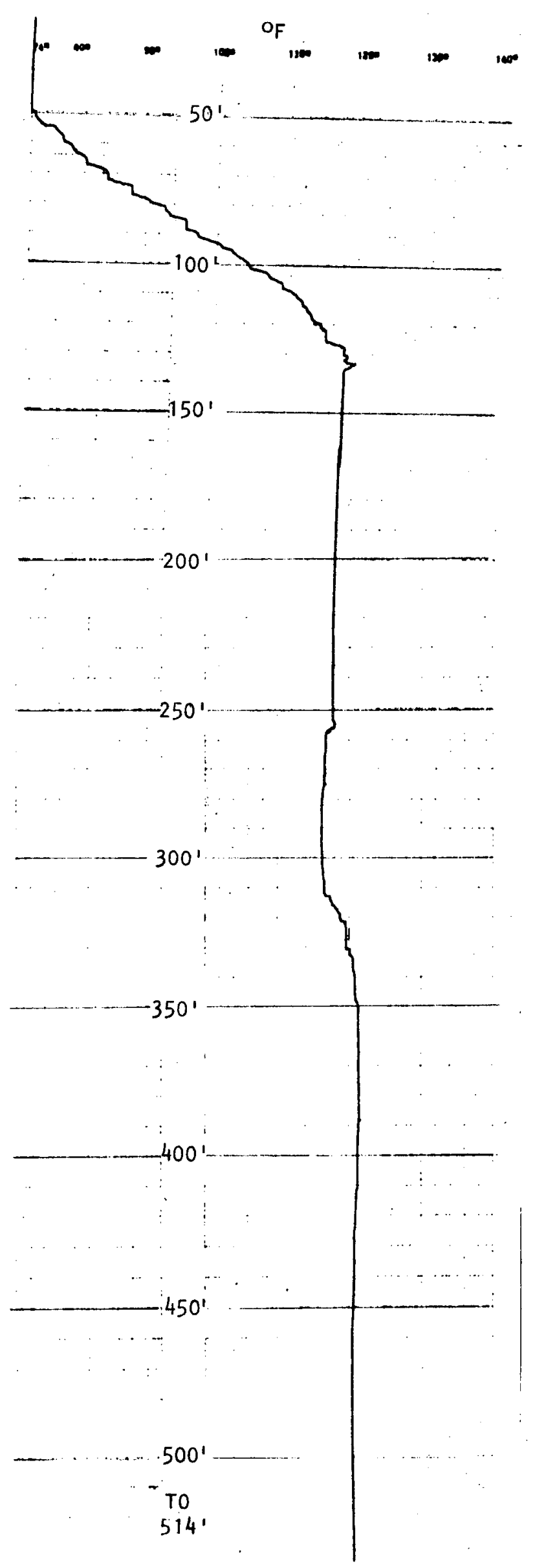

Figure 2. Temperature $\log$ of the Wel1, October 25, 1981 
TABLE 1. WATER CHEMISTRY OF GLENWOOD SPRINGS* DATE SAMPLED: $7 / 75$

Arsenic (As), $\mu \mathrm{g} / \mathrm{T}$

0

Boron (B), $\mu \mathrm{g} / 1$

800

Cadmi um ( $\mathrm{Cd}$ ), $\mu \mathrm{g} / \mathrm{I}$

0

Calcium ( $\mathrm{Ca}), \mathrm{mg} / 1$

410

Chloride $(\mathrm{Cl}), \mathrm{mg} / \mathrm{l}$

9,600

Fluoride $(F), \mathrm{mg} / \mathrm{l}$

2.2

Iron $(\mathrm{Fe}), \mu \mathrm{g} / \mathrm{l}$.

40

Lithium ( $L i), \mu g / 1$

730

Magnesi um $(\mathrm{Mg}), \mathrm{mg} / \mathrm{l} \quad 88$

Manganese $(M n), \mu g / 7 \quad \therefore \quad 70$

Mercury $(\mathrm{Hg}), \mu \mathrm{g} / 1 \quad 0$

Nitrogen $(\mathrm{N}), \mathrm{mg} / \mathrm{T} \quad \ldots .01$

Phosphate $\left(\mathrm{PO}_{4}\right)$ Ortho dissolved as $P, \mathrm{mg} / 1 \quad 0.03$

Ortho, mg/l

0.09

Potassium (K), mg/1 160

Selenium $(\mathrm{Se}), \mu \mathrm{g} / 1 \quad 0$

Silica $\left(\mathrm{SiO}_{2}\right), \mathrm{mg} / \mathrm{l} \quad 30$

Sodium $(\mathrm{Na}), \mathrm{mg} / 1 \ldots 6,000$

Sulfate $\left(\mathrm{SO}_{4}\right), \mathrm{mg} / 1, \ldots 90$

Zinc $(Z n), \mu \mathrm{g} / 1$. 20

Alkalinity

As calcium carbonate, $\mathrm{mg} / \mathrm{l} \quad 604$

As bicarbonate, $\mathrm{mg} / 1$. 736

Hardness

Noncarbonate, $\mathrm{mg} / \mathrm{l} \quad 780$

Total, mg/l $\quad 1,400$

Specific conductance,

micromohs

31,000

Total dissolved solids (TDS), $\mathrm{mg} / 1$

17,600

$\mathrm{pH}$, field

6.3

Discharge (gpm)

$2-3 \mathrm{E}$

Temperature, ${ }^{\circ} \mathrm{C}$

44

*Reference: Municipal Geothermal Heat Utilization Plan for Glenwood Springs, Colorado, Final Report, Prepared by University of Denver, Denver Research Insti tute, Denver, C0, December 31, 1980. 
Coury and Associates, Inc.

The temperature, gamma radiation, and caliper logs all suggest a permeable production zone at depths from 250 to 350 feet. 0ther permeable zones for reinjection are located at depths from 400 feet to total depth in increments of about 25 feet. Figure 4 show's a schematic diagram of planned well completion. Water level in the well is about 20 feet below the surface. A pump will be set at 200 feet and will draw water from 250 to 350 feet. A well screen will be placed in the well at this depth to permit water to enter the casing. The water will be brought to the surface, run through the heat exchangers and sent to the bottom of the well through a 3-inch tubing. A packer in the casing at 400 feet will eliminate the possibility of short circuiting in the casing. A seal will also be placed outside the casing to eliminate the short circuiting of cold water up the annulus of the well casing and well bore.

\section{BUILDING DESIGN}

The building is initially designed for 9000 square feet of office space. It can be expanded to nearly 27,000 square feet. Phase I will be a three-story building (garden level and two stories above ground) totalling about 9000 square feet. Phase II will consist of a five-story addition, elevated above or over ground level parking, with a total project of about 27,000 square feet. There are three independent heating loads in the building. These are a space and hot water heating system, a hot tub, and a deicing system. The design loads for each of these heat uses for both Phase I and Phase II are presented in Table 2. The space heating of the building is accomplished with a central forced-air system. A variable air flow multi-zone system is used to permit individual temperature control in each room. The temperature of the geothermal fluid is too low to drive adsorption equipment. Fortunately, space cooling of the building is not needed due to climatic conditions and elevations. The deicing system operates with 1 -inch steel pipes encased in the concrete, separated by 12 inches. An ethylene glycol mixture is circulated through the piping network of the deicing system. The estimated annual heat consumption for the building, as estimated by the architect, is $450 \mathrm{million}$ Btu/yr for the initial construction phase. Consultation with the architect should continue in the selection of the final heating system. 
FIGURE 4 - PROPOSED GEOTHERMAL WELL COMPLETION

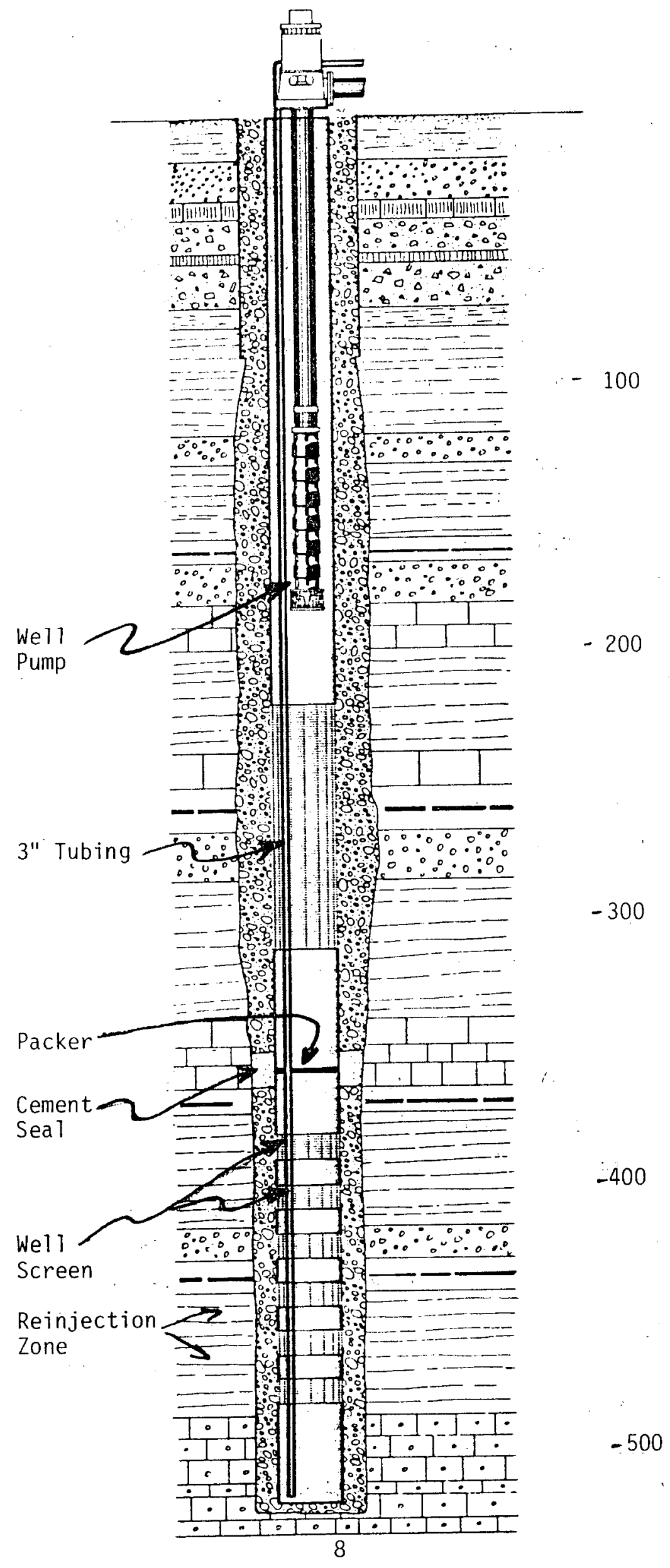


Coury and Associates, Inc.

TABLE 2. DESIGN HEAT LOADS (Btu/hr)

Heating Load

Hot Tub

Space and Hot Water

Deicing
Phase I

Initial Construction

45,000

250,000

52,000
Phase II

Building Completion

$$
\begin{array}{r}
45,000 \\
675,000 \\
52,000
\end{array}
$$


Coury and Associates, Inc.

\section{PROCESS DESIGN}

\section{DOWNHOLE HEAT EXCHANGER}

A brief analysis was made of the practicality of using a downhole heat exchanger in this service. This system circulates clean water within a closed loop. The water is first heated within heat transfer tubing installed in the well itself, and then is passed through a heat exchanger located inside the building where the heat is released to the forced-air heating system; cooled water leaving the building is sent back to the downhole heat exchanger (DHE).

The clean water within the DHE is heated by geothermal brine which passes over the outside surface of the heat transfer tubing. The hot brine passes from the aquifer to the open well bore, flows over the heat transfer tubing to give up its heat, and then reenters the aquifer and flows away from the well bore. The mechanism by which this flow phenomenon of the brine occurs is complex. Natural convection forces must be present in sufficient magnitude to overcome friction forces, as the brine flows over the tubing at a rate that is fast enough both to supply the total required amount of heat energy and to generate a heat transfer coefficient that is large enough to transfer this heat energy through the available tubing surface area. Then, after the dissipation of energy caused by this flow, the cooled brine must develop enough pressure so that it can force its way back into the reservoir at a location where it will not interfere with the incoming hot brine.

The potential advantages of a DHE are evident and significant: if it will perform reliably, economically, and as designed. It is a simple system that requires no brine handling. With a heat exchanger located on the surface (SHE), the brine would have to be pumped from the well, through the SHE, and down an injection well. Despite potential advantages and the conceptual simplicity of the DHE system, it was not recommended for this service at Glenwood Springs because of the factors that are summarized below. 
Coury and Associates, Inc.

The primary factor against use of the DHE is that there is not enough information available to allow a determination of whether the system would work, or to allow a design to be prepared with any degree of confidence. At the present level of knowledge about the geothermal aquifer, any design of the DHE would have to be by trial and error and would be very costly. This is the case because the natural convection forces at work in the DHE system, as was described earlier, are very small and any small error in the data on reservoir conditions would make the system unworkable.

Other factors discourage the use of DHE systems for general applications, even when sufficient data for design are available. On the heat supply side of the system, the total brine flow over the heat exchanger is significantly less than the productive capacity of the well, and the efficiency of heat extraction from the brine is relatively low, so that the total heat production per well is low. Thus, DHE systems tend to be economical only when well costs are low and when the heat load is small, at the level of the heat load of one or two homes. Also, the heat transfer rate tends to be low, thus increasing the size of the heat exchanger. On the heat receiving side of the system, it is generally difficult to attain countercurrent flow with the DHE. Thus, the maximum temperature attainable by the circulating water is relatively low and this tends to increase the size and cost of the heat conversion system at the point of use.

When scaling or corrosion of the heat transfer tubing occurs because of the chemistry of the geothermal brine, maintenance and repairs are more difficult and costly with a DHE. Often, these problems with a brine can be prevented if the brine is kept under pressure and out of contact with air. Such control of the brine is often difficult or impossible, however, when a DHE is used.

\section{SURFACE HEAT EXCHANGERS}

The advantages and disadvantages of the surface heat exchanger (SHE) system tend to be just the opposite of those described for the DHE. On balance, the SHE system is generally preferred for reasons of economics and performance. When sufficient reservoir data are not available, the SHE should always be specified. 
Coury and Associates, Inc.

Being on the surface, the SHE is easily accessible for maintenance and cleaning. Better control of the brine is possible, so corrosion and scaling problems are less likely to occur. Cheaper heat exchanger designs are possible and more efficient extraction of the heat from the brine can be attained,

The primary apparent disadvantage of the SHE system as compared to the DHE system is that the geothermal brine must be pumped from the production well to the heat exchanger and then to the injection well. In practice, this is probably never actually a disadvantage when the user heat load is high, because the more efficient extraction of heat with a SHE will probably lead to lower overall costs for the wells. As previously mentioned, for low heat load facilities, the DHE allows the cooled brine to go back into the reservoir through the same well from which the brine was produced. When the geological conditions are such that a DHE system is technically possible, it would also be possible to inject the cooled brine from a SHE back into the production well, at a depth that is isolated from the production zone.

\section{APPLICATION TO THE WRIGHT WATER ENGINEERS SYSTEM}

The brine produced from the Wright Water Engineers well is too saline to be passed directly through radiators or convection heaters. Therefore, brine from the wells is pumped through a surface heat exchanger system to provide the heat to clean circulating fluid in each of three separate loops.

As mentioned in the previous chapter, there are three separate heat loads associated with the building. A hot tub has been included in the building design with a peak heating load of 45,000 Btu/hr. Space and water heating account for the largest heat requirement of $250,000 \mathrm{Btu} / \mathrm{hr}$ in Phase I and 675,000 Btu/hr in Phase II. The third heat load of 52,000 Btu/hr is for snow melting of sidewalks and parking. A separate heat exchanger has been specified for each of these heat loads due to their independent operation.

The geothermal fluid will cascade through the three plate heat exchangers as shown in Figure 5 . The geothermal fluid will pass first through the hot tub exchanger, then the space heating exchanger, and finally 


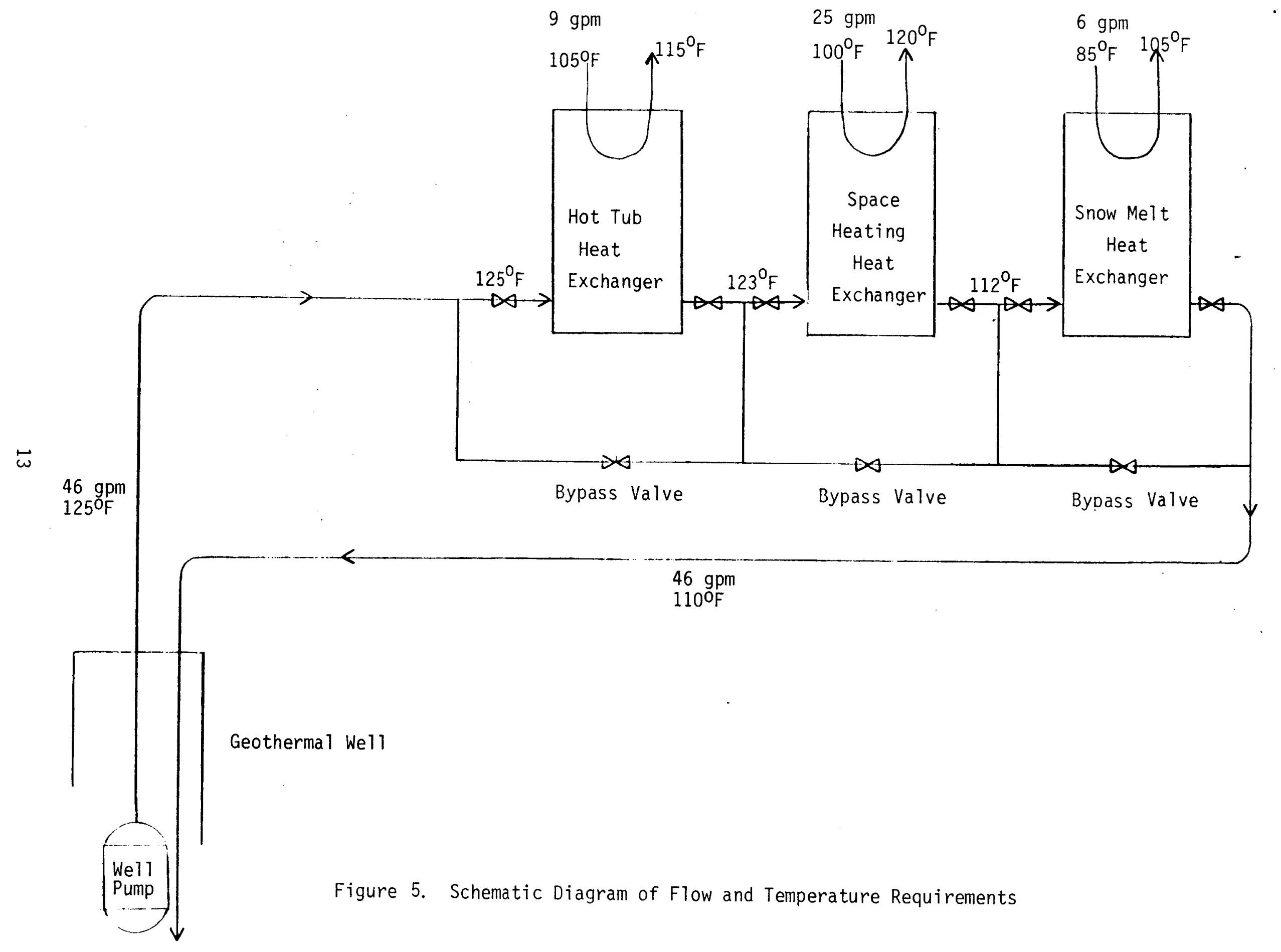


Coury and Associates, Inc.

through the deicing exchanger before disposal by reinjection. The hottest temperatures are required at the hot tub; therefore, the geothermal will provide this heating need first. When the building is expanded the temperature loss due to the hot tub heat load will be less than $1^{0} \mathrm{~F}$. The geothermal fluid is then used for space heating where large heat loads are supplied and, thus, geothermal temperature is lowered. The cooled geothermal fluid can then be used for the snow melting and deicing system. The water in the hot tub will be heated by passing directly through the heat exchanger. A closed loop of city water will be continuously heated in the space heating heat exchanger. A 50\% glycol-water mixture will be heated in the third heat exchanger for snow melting purposes. For the first phase of construction the combined heat loads will necessitate the use of $46 \mathrm{gpm}$ of geothermal fluid. When the building is expanded to its final design size in Phase II, the geothermal fluid flow requirement will increase to $103 \mathrm{gpm}$. The inlet and outlet temperatures of the circulating fluids and the geothermal fluids are presented in Table 3.

To provide as high a temperature as possible, the pipe transporting the fluid from the well to the heat exchangers should be insulated. The relatively low temperature of the geothermal resource will permit the use of several inexpensive preinsulated pipe products. Either a PVC or fiberglass insulated product should be suitable for the expected operating temperatures and pressures of $125^{\circ} \mathrm{F}$ and $40 \mathrm{psi}$.

A 2-inch diameter pipe could be used to provide the necessary flow from the well to the heat exchangers. However, to permit the necessary flow needed when the building is enlarged, a 3-inch diameter pipe should be specified. The estimated length of this pipe run is about 40 feet. A buried direct route for the pipe from the well to the heat exchangers is suggested. An uninsulated pipe may be used to return the water to the well. This pipe should be buried next to the insulated pipe.

\section{MATERIALS SELECTION}

General corrosion problems due to the saline situation are not expected to be serious because the temperatures are low and, more importantiy, 
Coury and Associates, Inc.

TABLE 3. TEMPERATURE AND FLOW REQUIREMENTS

Source of Heat Demand
PHASE I

Initial Building Construction

Temperature* $\left({ }^{0} \mathrm{~F}\right)$ gpm

Hot Tub, 45,000 Btu/hr

Geotherma 1

Circulating

Space Heating

250,000 Btu/hr

Phase I

$675,000 \mathrm{Btu} / \mathrm{hr}$

Phase II

Geotherma 1

Circulating
46

9

125

105
123

115
PHASE II

Future Building Completion

Flow $\frac{\text { Temperature* }\left({ }^{O} F\right)}{\text { In }}$

gpm

$\begin{array}{rrr}103 & 125 & 124 \\ 9 & 105 & 115\end{array}$

Deicing, 52,000 Btu/hr

Geothermal
Circulating

$\begin{array}{ll}46 & 123 \\ 25 & 100\end{array}$

112

103

124

111

120

67

100

120

46

112

110

103

111

110

6

85

105

6

85

105

* Temperatures rounded off to nearest ful1 degree 


\section{Coury and Associates, Inc.}

because the system will be kept under pressure, and air will not be allowed to contact the brine. This allows the use of steel for the well casing. The use of oil or paraffin at the air/water interface can be used for corrosion control. This application has been used very successfully at Klamath Falls, Oregon. The production screens, however, are normally made of stainless steel which is susceptible to stresscorrosion cracking in the presence of dissolved chlorides. To minimize this problem, an L grade of stainless can be specified, either $304 \mathrm{~L}$ or $316 \mathrm{~L}$. To further reduce the risk, solution annealing after welding can be specified for the screen. As long as oxygen is not present in the brine, solution annealing may not be necessary.

Other specific corrosion problems will be present, primarily due to the presence of dissolved $\mathrm{H}_{2} \mathrm{~S}$ gas in the brine. The design should not use any copper or copper alloys, for piping, valves, valve trim, seals, pump parts, or for any wetted surface, nor should it call for the use of natural rubber. Insulated fiberglass, PVC, or steel pipe is acceptable. Malleable cast iron or carbon steel pumps are suitable. 
Coury and Associates, Inc.

In this section, capital and operating costs are presented along with a discussion of tax incentives. Tax incentives should be considered as possible ways to offset the capital and operating costs.

\section{EQUIPMENT COSTS}

There are three major equipment items associated with the use of the geothermal resource, excluding the well costs. These are the well pump, the heat exchangers, and the piping from the well to the building and then back to the well. The estimated purchase and installation cost for the pump is $\$ 7150$. Installation costs include those to set the pump and provide electric service. The pump has the following design specifications:

Flow: $\quad 50 \mathrm{gpm}$

Head: $\quad 135 \mathrm{ft}$

Set depth: $200 \mathrm{ft}$ below surface

Water level: $50 \mathrm{ft}$ below surface

Power: $\quad 3 \mathrm{hp}$

Materials: No copper in any bearings or impeller

The plates for the heat exchangers will be made of 316 SS. The allowable pressure drop through each exchanger is 2 psi. The 2 psi value is 1 imited for both the geothermal side and the circulating fluid. The estimated costs for each of the heat exchangers are presented below. These values do not include installation.

$\begin{array}{lr}\text { Hot tub } & \$ 2500 \\ \text { Space heating } & 3400 \\ \text { Deicing } & 2700 \\ \text { Total } & \$ 8600\end{array}$

The cost for the piping needed to transport the geothermal fluid can be estimated using costs of $\$ 6.75 / \mathrm{ft}$ for the $3-\mathrm{in}$. insulated PVC pipe and $\$ 1 / f t$ for a 3-in. bare PVC pipe. Provisions must be made to allow for the thermal expansion of PVC pipe. The installation of the two pipes in a 
Coury and Associates, Inc.

common trench will cost about $\$ 6 / \mathrm{ft}$. At a length of $40 \mathrm{ft}$ for each pipe, the total cost of the geothermal supply and return pipeline will be $\$ 550$.

The total incremental equipment cost for the geothermal system is about $\$ 16,300$. The heating system inside the building is composed of a central forced air system which would be needed either with or without the geothermal supply.

OPERATING COSTS

The annual operating costs for the geothermal system consist of the electrical energy needs to operate the well pump. The 3-hp motor for the pump will operate year around. Based on current electric costs of $\$ 0.054 / \mathrm{kWh}$, the annual operating costs for the pump will be $\$ 1071$.

Natural gas is the primary heating source in Glenwood Springs. Taking into account the thermal efficiency of natural gas at this elevation, the effective cost of the gas if $\$ 6.24 / \mathrm{million} B$ tu. Based on this cost and an annual heat load of $450 \times 10^{6} \mathrm{Btu}$ 's, the annual cost savings in natural gas will be about $\$ 2800$.

The projected savings in operation of a geothermal heating system is the difference between the equivalent natural gas costs and the pumping costs. The anticipated annual savings will amount to about $\$ 1700$.

\section{TAX INCENTIVES}

The principal legislation and regulations governing energy credits and incentives available from the federal government and the State of Colorado are summarized on the following pages. These regulations apply to the following areas:

- Energy Tax Credit--an investment tax credit that may be applicable in addition to the existing investment tax credit

- Intangible Drilling Cost Deductions

- Depletion Allowance

For clarity of organization, these are discussed individually. The following summaries represent. our best understanding of the impact of the 


\section{Coury and Associates, Inc.}

tax law made available to us through review of pertinent documents and communication with other members of the geothermal community. Tax law and the regulations that provide guidance for compliance are detailed, complex subjects. We suggest that the following information be used as the basis for additional discussions with your tax consultant. 
FEDERAL ENERGY TAX CREDIT

Currently, the federal government allows an investment tax credit of $10 \%$. Alternative Energy Tax Credit provides for an additional 15\% investment tax credit above the regular investment credit. It may offset $100 \%$ of tax 7 iability remaining after applying the regular credit. For geothermal, the credit expires after 1985 .

The IRS Final Regulations, 26 CFR Part 1, Investment Credit for Energy Property, provide guidance to compliance with the Energy Tax Act of 1978. See Federal Register v. 46, no. 15, January 23, 1981. The crude-oil Windfall Profit Tax Act, passed March 1, 1980, expanded the scope and extended the timetable for gaining these credits.

\section{Definitions and Eligibility Criteria}

Alternative energy property includes:

- Equipment which uses an alternate substance as a fuel.

- Pollution control equipment eligible if installed in connection with eligible alternative energy property.

- Equipment used to produce, distribute, or use energy derived from a geothermal deposit. Although the wellhead temperature cited is $>50^{\circ} \mathrm{C}\left(122^{\circ} \mathrm{F}\right)$, this is subject to interpretation.

1. Must be specifically adapted to use geothermal energy.

2. Must be used exclusively with energy derived from a geothermal deposit.

a. Production equipment (to bring energy to surface): wellhead and downhole equipment; screening or slotted liners, tubing and downhole pumps; reinjection well property.

b. Distribution equipment--transport to site of ultimate use; components of a heating system, e.g. pipes and ductwork within a building.

c. Exclusive: not eligible are:

--A backup system using other water

--Addition of heat before circulation (geothermal water not hot enough); neither boiler nor circulating system is geothermal equipment in that situation 
INTANGIBLE DRILLING COST DEDUCTIONS

Sec. 402, Energy Tax Act of 1978

\section{A. OPTION TO DEDUCT INTANGIBLE DRILLING COSTS}

For tax purposes, the costs of drilling and completing a geothermal well are divided into two classes: intangible drilling costs and capital costs. Capital costs must be recovered through depreciation.

Intangible drilling costs are those incurred which, in themselves, have no salvage value and which are "incident to and necessary for the drilling of wells..." Such expenditures expressly include "wages, fuel, repairs, hauling, supplies, etc." that are used: (1) in the drilling and cleaning of wells; (2) in such clearing of ground, draining, road making, surveying, and geological and hydrological evaluations as are necessary in preparation for the drilling of the wells; and ( 3 ) in the construction of such derricks, tanks, pipelines, and other physical structures as are necessary for the drilling of wells and the preparation of wells for production.

They may be expensed (deducted as expenses) in the year in which they were incurred or they may be capitalized and deducted over a certain period of time as depreciation. Allowing a taxpayer to expense (deduct) all the intangibles in the year in which they were incurred gives the taxpayer an "accelerated depreciation."

The taxpayer must make his election to expense or to capitalize intangibles in the first taxable year in which he incurs such costs. Once having done so, the taxpayer must treat such expenditures on all geothermal properties in the same manner for all future years. However, if the taxpayer elects to capitalize his intangibles, he is granted a second election to capitalize or to expense the portion of intangibles attributable to dry or nonproductive wells.

\section{B. PREFERENCE INCOME--MINIMUM TAX}

Some types of income are given preferential treatment by special provisions of the tax law. A minimum tax applies to a number of items that are considered to be of a tax-preference nature. These types of 
income include capital gains, stock options and income offset by depletion, amortization and intangible drilling costs. The tax is computed by totaling a 11 the $i$ tems of tax preference, then reducing this amount by the greater of $\$ 10,000$ or one-half a taxpayer's regular income tax after reduction by credits. A flat $15 \%$ rate is then applied against the balance. Preference income is applied differently to individual taxpayers as compared to corporations.

If certain taxpayers have "excess intangible drilling costs" that exceed net geothermal income, he will have preference income subject to the minimum tax. Intangible drilling costs are considered to be excessive when the intangible drilling and development costs of a geothermal well al lowable for the tax year is greater than the sum of: (1) the amount allowable if the costs had been capitalized and straight-line recovery of intangibles had been used; and (2) the net income for the tax year from the geothermal property.

Straight-line recovery means the ratable amortization of such intangibles over the 120-month period beginning with the month in which production from the well begins (or, if elected, any method which would be permitted for purposes of determining cost depletion). Net income from geothermal properties means the gross income from all such property reduced by any deductions allocable to the properties, except intangible drilling and development costs in excess of straight-line recovery.

This preference does not apply to taxpayers who elect to capitalize their intangibles by straight-line recovery; nor does it apply to nonproductive wells. In effect, what this provision does is to lessen the benefit of the option to expense intangible drilling costs. Few taxpayers now have geothermal income and if they choose to expense intangibles, they wi 11. have preference income; i.e., the amount they deduct by expensing intangibles will be greater than the sum of intangibles capitalized and net geothermal income. This preference tax on intangible drilling deductions is not applicable, however, to corporations. 
DEPLETION ALLOWANCE

The owner of an economic interest in a geothermal resource may recover $h$ is cost through federal tax deductions for depletion over the economic life of the property.

The IRS provides two methods of computing a depletion allowance: cost depletion and percentage depletion. Cost depletion provides for a deduction for the taxpayer's basis (cost) in the property in relation to the production and sale of minerals from the property. On the other hand, percentage depletion is a statutory concept that provides for a deduction of specified percentages of the gross income from the property. The deduction, however, can not exceed $50 \%$ of the net income from the property. A taxpayer is required to compute depletion both ways and to claim the larger of the two amounts.

A depletion allowance reduces the taxpayer's basis in a property but the total amount taken as a depletion allowance is not restricted to the taxpayer's basis. Even though cost depletion will be zero after the taxpayer's initial basis has been recovered (for example, T deducts $\$ 5000$ per year for five years for a total of $\$ 25,000--$ the amount of his original investment), the taxpayer may continue to claim percentage depletion based on income from the property.

Section 403 of the 1978 Energy Tax Act grants percentage depletion on income from geothermal deposits. The rate through 1980 is $22 \%$. It decreases by $2 \%$ yearly until 1983 and thereafter the rate is 15\%; thus, the 1981 percentage is $20 \%$.

There is some question about the availability of depletion on minerals which are consumed by the producer of such minerals. One way for the corporate taxpayer to avoid the problem is to conduct its exploration and development activities through a wholly owned subsidiary. 
A commercial or industrial taxpayer can subtract from the state income tax bill 10\% of the cost of any "energy property" provided the expenditures are made during taxable years 1981 through 1986.

The state credit includes all the energy properties defined under the 1978 Federal Energy Tax. Act, but excludes pollution control equipment. Alternative energy properties include equipment to generate heat from a geothermal deposit. Heat pumps are specifically excluded.

The state's investment tax credit applies to expenditures up to $\$ 1.25$ million for the 1981 taxable year, $\$ 1.75$ million for the 1982 taxable year, and $\$ 2.25$ million for the $1983,1984,: 1985$, and 1986 taxable years. The credits can be carried forward five years if they exceed tax liability.

\section{ECONOMIC SUMMARY}

The capital costs for items associated with the geothermal heating system which are subject to the alternate energy tax credits are identified in Table 4. The tangible drilling costs for the well completion have been included in the table below since they may be included in calculating the tax credits.

TABLE 4. CAPITAL COSTS FOR GEOTHERMAL HEATING SYSTEM

$$
\begin{array}{lr}
\text { Geothermal Equipment } \\
\text { Well Pump } & 7,150 \\
\text { Piping } & 550 \\
\text { Plate Heat Exchangers } & 8,600 \\
\text { Heating System } & 120,000 \\
\text { Tangible Drilling Costs* } & 15,000
\end{array}
$$

\footnotetext{
*Assumption has been made that the tota 1 well costs are $\$ 60,000$. All costs have not been compiled for the particular well drilled; however, this value is believed to be representative.
} 
Coury and Associates, Inc.

The alternative energy tax credit available through State and federal regulations totals $25 \%$ of a 11 geothermal associated costs. In this particular case the tax credit is $\$ 37,800$. Additionally, the intangible drilling costs of $\$ 45,000$ can be treated as a business expense. Assuming a tax rate of $33 \%$, the intangible drilling costs will result in a $\$ 15,000$ savings. The after-tax capital costs are presented below in Table 5. The table presents the capital costs for two cases--with and without estimated well costs. The depletion allowance has not been included in any of these figures.

TABLE 5. AFTER-TAX CAPITAL COSTS

Excluding Well Cost Including Well Cost

Well cost $\$ 60,000$

Geothermal System

$\$ 16,300$

16,300

Initial Capital Costs

$\$ 16,300$

$\$ 76,300$

Less Available Tax Credit

$\$ 34,100$

$\$ 37,800$

Less Intangible Drilling

Cost Tax Savings

Capital Costs After

First Year

$-\$ 17,800$

$\$ 23,500$

The annual operating expense is related to electric costs for operation of the well pump. The maintenance costs are estimated at $\$ 300$ per year. Table 6 presents the estimated annual costs and savings for the geothermal heating system.

TABLE 6. ESTIMATED ANNUAL COSTS AND SAVINGS FOR SYSTEM

Savings

Fossil Fuel Savings

Less:

Operating Costs

Maintenance Costs

Net Annual Savings
$\$ / y r$

2,800

$\$ 15,000$

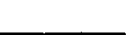


Coury and Associates, Inc.

The simple payback period on the system is calculated by dividing the annual savings into the capitalized costs. For the case where well costs are included, the payback time is about 16 years. If the costs of the well are not included, the available tax savings exceed the costs for geothermal equipment. The compound payback period, assuming an interest rate on borrowed money and escalating energy costs, cannot be evaluated if interest rates for money exceed the escalation of fue 1 prices. The Phase II building expansion will create a significantly larger heat load which will still be able to be served with the current well and with only minimal additional capital cost. Therefore, the economics of the overall system will measurably improve in future years when that expansion is realized. 
Coury and Associates, Inc.

IV. FUTURE WORK

The conceptual design of the heating system, the approximate sizing of equipment, and the operational and control procedures have been completed. The final specifications are being prepared by Wright Water Engineers; these activities are primarily related to evaluating the aquifer and the well design, and they are tasks that would ordinarily have been undertaken earlier except for special problems related to well-testing permits. These activities are described below.

The well will be tested to verify the best productive zones and brine temperatures as they are related to various production depths. A pumping test will be run to determine well characteristics. An injection test is also anticipated. If these tests indicate vertical connection between the production and injection zones, a cement plug will be set from the top of the reinjection zone to the base of the production zones. The well drawdown will be determined as a function of production rate, along with the injection pressure needed in the wellbore at the bottom of the well. On the basis of this information, the final design of the pumping system and line sizes can be made. A primary decision to be made at that time is whether the downhole pump alone should provide all the work to produce, distribute and inject the brine, or whether the downhole pump should simply produce the brine while a second pump at the surface distributes and injects the produced brine.

On the bașis of the well testing data, a more exact analysis of a downhole heat exchanger can be made for this specific service. Since the heat loads for the first phase of the building development are relatively small, it is possible that a DHE, although inefficient, would be costeffective until the building expansion takes place.

After the system is in operation, there will be a limited period of monitoring performance of the entire system and evaluating the data. This evaluation will have two objectives. The first will be to determine the long-range capacity and reliability of the production well. The second will be to determine if the geothermal resource is adequate for providing the projected heating load for the expected, full-size building. 